\title{
THE FUTURE OF THE AMERICAN MILITARY PRESENCE IN EUROPE
}

\author{
Lloyd J. Matthews \\ Editor

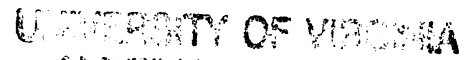

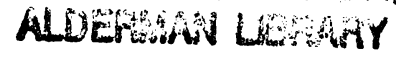 \\ INI 102001 \\ rino Ex

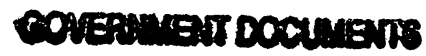

May 2000 